\title{
Tumor targeting with docosahexaenoic acid-conjugated docetaxel for inhibiting lung cancer metastasis to bone
}

\author{
SHOUGANG JIANG ${ }^{1,2^{*}}$, ZHIGUO LIU ${ }^{1,2^{*}}$, LEI WU ${ }^{1,2}$, YINGJIE YUAN ${ }^{1,2}$, YAN HU $^{1,2}$, \\ XINGYAO ZHANG ${ }^{1,2}$, LIANG WEI ${ }^{1,2}$ and YUANGANG ZU ${ }^{1,2}$ \\ ${ }^{1}$ Key Laboratory of Forest Plant Ecology, Ministry of Education; ${ }^{2}$ State Engineering Laboratory of \\ Bio-Resources Eco-Utilization, Northeast Forestry University, Harbin, Heilongjiang 150040, P.R. China
}

Received July 7, 2017; Accepted May 11, 2018

DOI: $10.3892 / \mathrm{ol} .2018 .9047$

\begin{abstract}
Docetaxel (DTX) is currently used as a first- or second-line drug treatment for patients with lung cancer, however, it is less effective for the treatment of patients with bone metastasis of lung cancer. This is primarily due to the fact that docetaxel is nonspecific. In the present study, docosahexaenoic acid (DHA) was selected as a tumor-targeting ligand, and DHA-conjugated DTX (DTX-DHA) was prepared for inhibiting lung cancer metastasis to bone. The anti-cancer activity assay revealed that DTX-DHA exhibited a similar antitumor efficacy to DTX in vitro. The maximum tolerated dose of DTX-DHA was increased compared with that of DTX. The present study results indicated that DTX-DHA exhibited an improved inhibition efficacy of lung cancer metastasis to bone in comparison with DTX in vivo. Encouragingly, the mean survival time of the DTX-DHA group (30.60 days) was increased compared with the DTX group (26.10 days; $\mathrm{P}<0.01)$. Furthermore, the results of cell migration and osteoclast-induced formation assays suggested that DTX-DHA inhibited lung cancer metastasis to bone primarily by affecting lung cancer cell migration. These results indicate that DTX-DHA may exhibit a potential therapeutic effect against lung cancer metastasis to bone.
\end{abstract}

\section{Introduction}

Among patients with lung cancer, $40 \%$ develop bone metastasis with a relatively short median survival time in Japan in 1981, and the metastatic disease currently lacks an effective

Correspondence to: Dr Yuangang $\mathrm{Zu}$, Key Laboratory of Forest Plant Ecology, Ministry of Education, Northeast Forestry University, 26 Hexing Road, Harbin, Heilongjiang 150040, P.R. China

E-mail: cpu127@126.com

${ }^{*}$ Contributed equally

Key words: docosahexaenoic acid-conjugated docetaxel, tumor vascular endothelium targeting, lung cancer metastasis to bone, antitumor activity therapeutic strategy (1). Bone-modifying agents (diphosphonates) reduce skeletal-associated events (pathologic fracture, spinal cord compression and radiation or surgery to bone), however, they do not significantly improve overall survival (1). Therefore, novel and effective therapeutic approaches for the metastatic disease are urgently required.

Docetaxel (DTX; Fig. 1A) is currently used as a first- or second-line treatment for patients with lung cancer, however, it is less effective for the treatment of patients with bone metastasis of lung cancer $(2,3)$. Since DTX may cause serious bone marrow inhibition in patients, it is unable to reach a therapeutic concentration at the lesion sites of skeletal metastases (4). Therefore, the lack of discrimination of DTX between neoplastic and healthy cells is a key reason that it demonstrates poor efficacy in the treatment of lung cancer metastasis to bone.

Lung cancer is highly heterogeneous histologically and molecularly, and as a result, only a small number of drug targets for lung cancer have been identified $(5,6)$. Fortunately, phosphatidylethanolamine becomes exposed on the tumor vascular endothelium of lung tumors, and not on normal vessels and cells $(7,8)$. Notably, it has been identified that docosahexaenoic acid (DHA; Fig. 1B) is a ligand of phosphatidylethanolamine (9). Furthermore, DHA is safe for clinic application as it is an endogenous compound (10).

It has previously been identified that DHA is an inhibitor of breast cancer metastasis to bone (11). It has also been demonstrated that DHA supplementation increases first-line chemotherapy efficacy in patients with advanced non-small cell lung cancer $(12,13)$. A possible underlying molecular mechanism is that DHA significantly reduces E-selectin expression at the endothelial cell surface $(14,15)$. Since DTX, which is conjugated to DHA, may be hydrolyzed back to DTX and DHA in vivo, DHA is not only a tumor-targeting ligand, but also a synergist of DTX for inhibiting lung cancer metastasis to bone $(12,16)$.

An innovative DTX-loaded bovine serum albumin (BSA)-coupled DHA nanoparticle (DTX-DHA-BSA-NP) for inhibiting lung cancer metastasis to bone was successfully prepared by the authors' research group. A previous study identified that the mean survival of the nanoparticles was longer than that of DTX (17). However, due to the immunogenicity of BSA, intravenous administration of 
DTX-DHA-BSA-NPs in humans may cause allergic reactions. Furthermore, DTX-DHA-BSA-NPs are difficult to produce on an industrial scale due to their complex preparation process $(18,19)$. Based on the clinical studies on DHA-paclitaxel for the treatment of metastatic malignant melanoma, esophago-gastric cancer and advanced non-small cell lung cancer, DHA was conjugated to DTX (DTX-DHA, Fig. 1C) by chemical means, in order to explore its effect on lung cancer metastasis to bone (20-23).

\section{Materials and methods}

Materials. DHA was purchased from Nu-Chek Prep Inc. (Elysian, MS, USA). DTX was provided by Shanghai Jinhe Bio-Technology Co., Ltd. (Shanghai, China). 1,3-dicyclohexylcarbodiimide was purchased from J\&K Scientific Ltd. (Beijing, China). Methylene chloride and 4-dimethylaminopyridine were purchased from Aladdin Bio-Chem Technology Co., Ltd. (Shanghai, China). A tartrate-resistant acid phosphatase (TRAP) kit (cat. no. CS0740-1KT) was purchased from Sigma-Aldrich (Merck KGaA, Darmstadt, Germany). Macrophage colony-stimulating factor (M-CSF) and receptor activator of nuclear factor- $\kappa \mathrm{B}$ ligand (RANKL) were provided by $R \& D$ Systems, Inc. (Minneapolis, MN, USA). C57BL/6 mice were purchased from Harbin Veterinary Research Institute (Harbin, China). Dulbecco's modified Eagle's medium (DMEM) and RPMI-1640 media were purchased from HyClone (GE Healthcare Life Sciences, Logan, UT, USA). A549 human lung carcinoma cells and LLC murine Lewis lung carcinoma cells were purchased from the Affiliated Tumor Hospital of Harbin Medical University (Harbin, China). RAW 264.7 murine macrophage cells were purchased from Shanghai Institutes for Biological Sciences (Shanghai, China). An alkaline phosphatase (ALP) assay kit (cat. no. AP0100-1KT) was purchased from Sigma-Aldrich (Merck KGaA). All other materials were purchased from Beyotime Institute of Biotechnology (Haimen, China).

Synthesis of DTX-DHA. DTX-DHA was synthesized from DTX and DHA with a one-step reaction that coupled DHA to DTX at the 2'-hydroxyl position. In brief, DHA (13.5 mg), 1,3-dicyclohexylcarbodiimide $(16.9 \mathrm{mg})$ and 4-dimethylaminopyridine $(5 \mathrm{mg})$ were added to the solution of DTX $(33 \mathrm{mg})$ in dichloromethane $(2.5 \mathrm{ml})$ under nitrogen. The reaction mixture was stirred at room temperature for $2 \mathrm{~h}$. Following dilution with ethyl ether (1:10), the reaction mixture was washed with $5 \%$ aqueous hydrochloric acid, distilled water and saturated aqueous sodium chloride in turn at room temperature. The mixture was concentrated by evaporating under a vacuum at $40^{\circ} \mathrm{C}$ with anhydrous sodium sulfate as the desiccant. Column chromatography (10 g silica gel stationary phase; $60 \mathrm{ml}$ acetic ether-hexane mobile phase) of the residue produced $43 \mathrm{mg}$ (95\%) solid DHA-DTX at room temperature. In all experiments described subsequently, DTX and DTX-DHA were formulated in a 50\% Tween-80/ethanol/normal saline mixture (2:1:97, respectively) (24).

Cell lines. A549 and LLC cells were used to perform cell migration and cell proliferation assays. RAW 264.7 and LLC cells were used to perform the osteoclast-induced formation assay. All cells were cultured in RPMI-1640 or DMEM with $10 \%$ heat-inactivated fetal bovine serum (FBS) and $0.1 \%$ antibiotics, and incubated in a humidified $5 \% \mathrm{CO}_{2}$ atmosphere at $37^{\circ} \mathrm{C}$.

Determination of anti-cancer activity in vitro. DHA-DTX was evaluated in vitro for anti-proliferative activity against LLC and A549 cells using an MTT assay. Tumor cells were seeded into sterile 96 -well plates $\left(1 \times 10^{4}\right.$ cells/well) in RPMI-1640 or DMEM (10\% FBS) medium and incubated at $37^{\circ} \mathrm{C}$ for $24 \mathrm{~h}$. The DTX-DHA and DTX were first dissolved in dimethyl sulfoxide (DMSO), then diluted in RPMI-1640 or DMEM medium culture solution with final DMSO concentration of $0.5 \%(\mathrm{v} / \mathrm{v})$. The tumor cells were treated with DTX or DTX-DHA at five different concentrations $(0,0.005,0.05,0.5$ and $5 \mu \mathrm{M})$, with three replicates, and incubated for 48 or $72 \mathrm{~h}$. Then, $10 \mu \mathrm{l}$ MTT was added to the cell culture medium prior to incubation for a further $4 \mathrm{~h}$. Subsequently, the supernatants were replaced with DMSO. The optical density was determined using a Microplate Reader (MD SpectraMax M5) at $490 \mathrm{~nm}$ (25).

Cell migration assay. A Transwell migration assay was performed using LLC cells. First, LLC cells $\left(1 \times 10^{5}\right)$ were seeded in the upper cell chamber with $600 \mu 1$ serum-free DMEM, $50 \mathrm{nM}$ DTX or $50 \mathrm{nM}$ DTX-DHA, and incubated at $37^{\circ} \mathrm{C}$ for $48 \mathrm{~h}$ before fixing with $4 \%$ paraformaldehyde at $4^{\circ} \mathrm{C}$ for $30 \mathrm{~min}$. LLC cells that migrated from the cell upper chamber to the 6 -well plates were observed under a light microscope (magnification, x200) following staining with crystal violet at room temperature for $30 \mathrm{~min}$ (26). The transmittance was calculated according to the following equation: Transmittance $=\left(\right.$ cells $_{\text {control group }}-$ cells $\left._{\text {drug group }}\right) /$ cells $_{\text {control group }}$ $\mathrm{x} 100 \%$.

Osteoclast-induced formation assay. In vitro osteoclastogenesis assays were performed to assess the effects of DTX-DHA on osteoclast differentiation. A total of $2.5 \times 10^{5} \mathrm{RAW} 264.7$ cells and LLC cells (10:1) were incubated at $37^{\circ} \mathrm{C}$ for $48 \mathrm{~h}$ in 48 -well plates. Subsequently, the cells were incubated at $37^{\circ} \mathrm{C}$ in complete cell culture medium containing $10 \mathrm{ng} / \mathrm{ml}$ murine recombinant RANKL and $10 \mathrm{ng} / \mathrm{ml}$ murine recombinant M-CSF following proliferation in 48-well plates for $24 \mathrm{~h}$. Then, the cells were treated with RPMI-1640 culture medium, $50 \mathrm{nM}$ DTX, $50 \mathrm{nM}$ DTX-DHA or $250 \mathrm{nM}$ DTX-DHA for $72 \mathrm{~h}$. Subsequently, TRAP staining was performed according to the manufacturer's protocol (26).

Evaluation of maximum tolerated dose (MTD). All animal procedures were performed following the protocol approved by the Institutional Animal Care and Use Committee at The State Engineering Laboratory of Bio-Resources Eco-Utilization, Northeast Forestry University (Harbin, China). Initial evaluation of tolerability of DTX-DHA and DTX were determined in healthy 6-week-old female C57BL/6 mice (18-22 g). A total of 42 mice were caged in groups of three, provided with ad libitum commercial mouse chow and water, and maintained on a $12 \mathrm{~h}$ light-dark cycle at a temperature of $23 \pm 1^{\circ} \mathrm{C}$. The dose of DTX in the in vitro assay for anti-cancer activity was $5 \mu \mathrm{mol} / \mathrm{kg}$, and $5 \mu \mathrm{mol} / \mathrm{kg}$ was 
A DTX

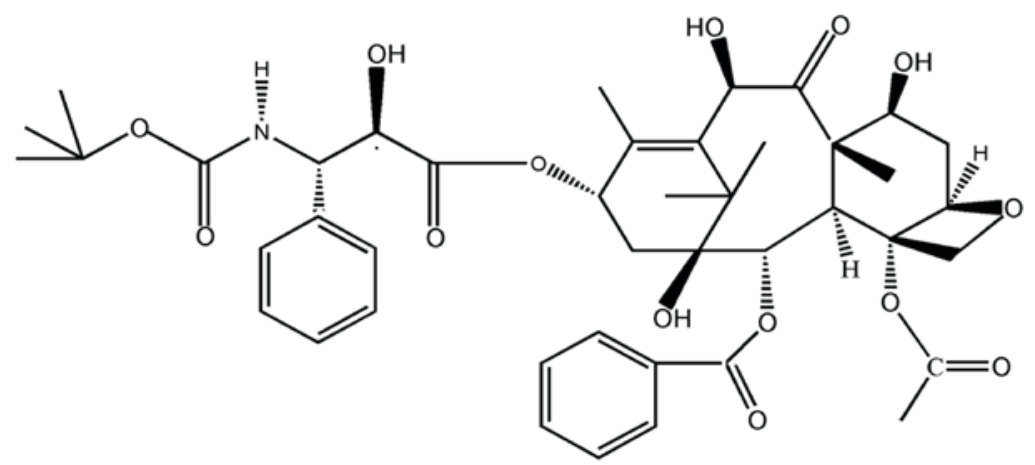

B DHA

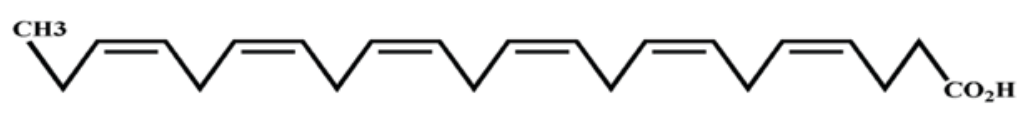

C

DTX-DHA

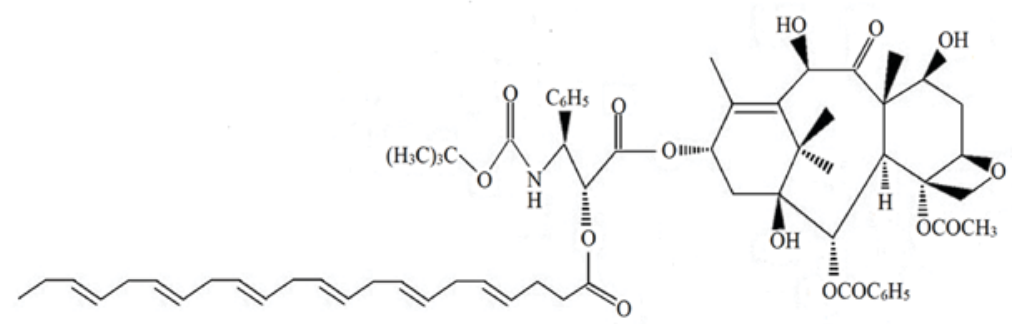

Figure 1. Chemical structure of DTX, DHA and DTX-DHA. (A) DTX. (B) DHA. (C) DTX-DHA. DTX, docetaxel; DHA, docosahexaenoic acid; DTX-DHA, docosahexaenoic acid-conjugated docetaxel.

selected as the minimum dose for the DTX-DHA to indicate the MTD. Furthermore, 10, 15, 20, 25, 30 and $35 \mu \mathrm{mol} / \mathrm{kg}$ were selected as the other six doses. Mice were administered intravenously with DTX or DTX-DHA. Drug effects were determined daily by monitoring of survival, body weight and overall health. The MTD was defined as the highest dose that caused neither toxic mortality nor $>10 \%$ body weight loss within a week of administration (27). The health of the mice was monitored daily via bodyweight measurement and observation of signs of distress, including apathy, loss of appetite, catatonia and prostration. Humane endpoints for this study included body weight loss $>20 \%$ and excessive signs of toxicity (pica behavior, lethargic or unresponsive).

In vivo assay of anti-cancer efficacy on lung cancer metastasis to bone. Ten female C57BL/6 mice (as described above) were used as a blank group for this study. All mice were injected with LLC cells $\left(10 \mu 1,1 \times 10^{6}\right.$ cells/ml) in the tibia of the right hind limb, then divided randomly into five groups $(n=20$ per group): Control group, DTX group (5 $\mu \mathrm{mol} / \mathrm{kg})$, DTX-DHA group $(5 \mu \mathrm{mol} / \mathrm{kg})$ and DTX-DHA group $(10 \mu \mathrm{mol} / \mathrm{kg})$. The treatments were administered intraperitoneally once daily for 10 days. The status of the mice was observed every day and the mice were weighed every 4 days. Tumors were measured daily using a caliper until the mice succumbed. Tumor volumes were estimated from two-dimensional measurements using the formula: Tumor volume $\left(\mathrm{mm}^{3}\right)=\left[\right.$ length $(\mathrm{mm}) \mathrm{x}$ width ${ }^{2}$ $\left.\left(\mathrm{mm}^{2}\right)\right] / 2$. A total of 14 days subsequent to injection with LLC cells, 3 mice from each group had blood extracted from their tails. Serum ALP concentration in the mice was determined according to the ALP activity detection kit (100T) protocol prior to sacrificing the mice $(11,27)$. Humane endpoints include body weight loss $>20 \%$ and excessive signs of toxicity (Pica behavior, lethargic, unresponsive).

$X$-ray radiography. Four weeks after the initial dose, mice were imaged using an X-ray machine (BL-X5, Zhengzhou Tianjie Electronic Equipment Co., Ltd., Zhengzhou, China) and the X-ray radiography images $(4 \times 3 \mathrm{~cm})$ revealed the bone injuries. The radiolucent osteolytic areas of bone metastasis were quantified for murine Lewis lung carcinoma cells using Quantity One 1-D analysis Software (version 4.6.9; Bio-Rad, Laboratories, Inc. Hercules, CA, USA) $(11,28)$.

Histopathological identification. Four weeks after the initial dose, the right hind limb bone of mice from the four groups 
Table I. Cytotoxic effects of DTX and DTX-DHA on LLC and A549 cell lines.

\begin{tabular}{|c|c|c|}
\hline \multirow[b]{2}{*}{ Sample } & \multicolumn{2}{|c|}{$\mathrm{IC}_{50}(\mu \mathrm{M}) \pm \mathrm{SD}$, time $=48 \mathrm{~h}$} \\
\hline & LLC & A549 \\
\hline DTX & $0.054 \pm 0.002$ & $9.780 \pm 0.046$ \\
\hline \multirow[t]{2}{*}{ DTX-DHA } & $0.045 \pm 0.001$ & $8.160 \pm 0.029$ \\
\hline & \multicolumn{2}{|c|}{$\mathrm{IC}_{50}(\mu \mathrm{M}) \pm \mathrm{SD}$, time $=72 \mathrm{~h}$} \\
\hline DTX & $0.023 \pm 0.002$ & $5.813 \pm 0.022$ \\
\hline DTX-DHA & $0.018 \pm 0.001$ & $4.951 \pm 0.015$ \\
\hline
\end{tabular}

Data are expressed as mean \pm SD. Data were analyzed using one-way analysis of variance and Student's t-test, $n=3, P<0.05$ vs. control group. DTX, docetaxel; DTX-DHA, docosahexaenoic acid-conjugated docetaxel; SD, standard deviation.

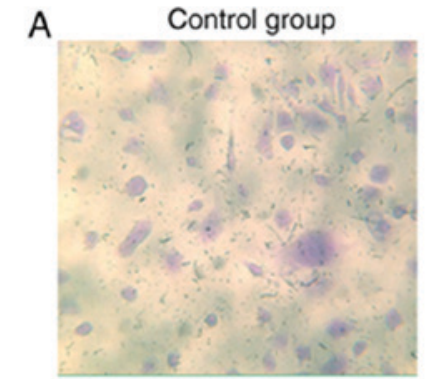

C

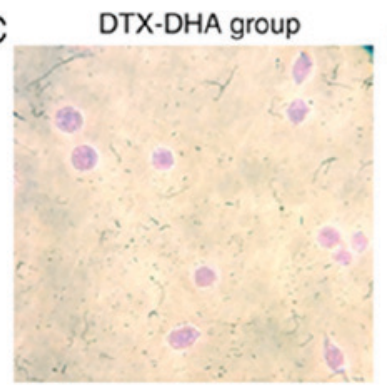

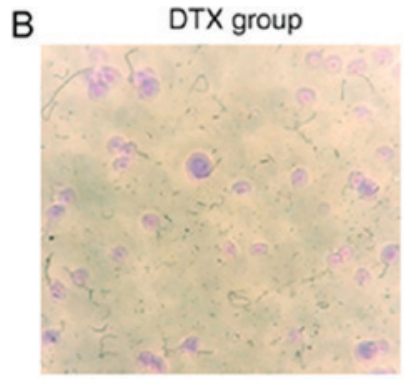

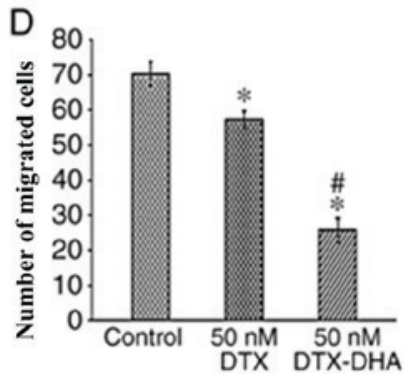

Figure 2. Microcopy images exhibiting cell migration. (A) LLC murine Lewis lung carcinoma cells that migrated from the chamber of the cell culture inserts to the 6-well plates and were stained with crystal violet following treatment with serum-free medium. (B) LLC murine Lewis lung carcinoma cells that migrated from the chamber of the cell culture inserts to the 6-well plates and were stained crystal violet following treatment with $50 \mathrm{nM}$ DTX. (C) LLC murine Lewis lung carcinoma cells that migrated from the chamber of the cell culture inserts to the 6-well plates and were stained with crystal violet following treatment with $50 \mathrm{nM}$ DTX-DHA. (D) Cell transmittance of DTX and DTX-DHA. Each value represents the mean \pm standard deviation of two independent triplicate cultures. Data were analyzed using one-way analysis of variance with Newman-Keuls post-hoc test. " $\mathrm{P}<0.01$ vs. Control; ${ }^{\text {"P }}<0.01$ vs. 50 nM DTX. Magnification, x200. DTX, docetaxel; DTX-DHA, docosahexaenoic acid-conjugated docetaxel.

was excised, fixed in $10 \%$ formalin in PBS (pH 7.2) at $4^{\circ} \mathrm{C}$ for $48 \mathrm{~h}$, then decalcified in $14 \%$ EDTA solution with agitation at room temperature for 2 weeks. Subsequently, samples were dehydrated in a graded series of ethanol (70,80,96 and 100\%) for $1 \mathrm{~h}$ each at $4^{\circ} \mathrm{C}$, embedded in paraffin and cut into $4.5-\mu \mathrm{m}$

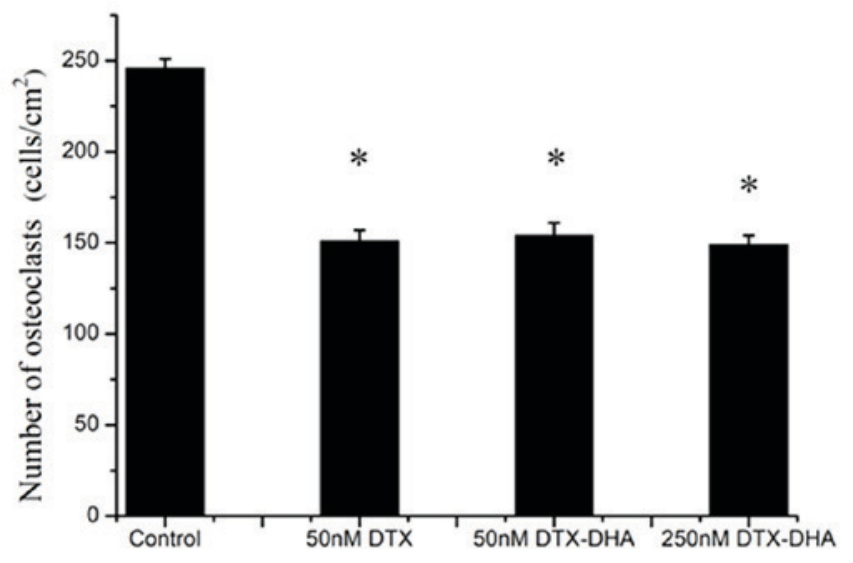

TRAP staining in different groups

Figure 3. The osteoclast-induced formation assay with TRAP staining was performed in vitro. RAW 264.7 murine macrophage cells were dyed with TRAP following treatment with saline, $50 \mathrm{nM}$ DTX, $50 \mathrm{nM}$ DTX-DHA and $250 \mathrm{nM}$ DTX-DHA. Each value represents the mean \pm standard deviation of two independent triplicate cultures. Data were analyzed using one-way analysis of variance with Newman-Keuls post-hoc test. ${ }^{*} \mathrm{P}<0.01$ vs. control. DTX, docetaxel; DTX-DHA, docosahexaenoic acid-conjugated docetaxel; TRAP, tartrate-resistant acid phosphatase.

thick sections. Samples were then deparaffinized in xylene at room temperature for $30 \mathrm{~min}$, stained with Mayer's hematoxylin solution at room temperature for $15 \mathrm{~min}$ and washed in water at room temperature for $20 \mathrm{~min}$. Then, samples were counterstained with $0.5 \%$ eosin for $1 \mathrm{~min}$, dehydrated in $95 \%$ ethanol and absolute ethanol for $4 \mathrm{~min}$ at room temperature, and cleared in xylene at room temperature for $4 \mathrm{~min}$. Then, the samples were observed under a light microscope (magnification, $\mathrm{x} 200)$ and tumor areas were quantified using Image-Pro Plus software (version 6.0; Media Cybernities, Silver Spring, MD, USA) $(27,28)$.

Statistical analysis. Data are presented as the mean \pm standard deviation. Data were analyzed using one-way analysis of variance with Newman-Keuls post-hoc test. P-values were calculated using log-rank (Mantel-Cox) tests on Kaplan-Meier survival curves. All statistical analysis was performed using SPSS software (IBM SPSS 19.0; https://myibm.ibm.com/products-services/products). $\mathrm{P}<0.05$ was considered to indicate a statistically significant difference.

\section{Results}

Determination of anti-cancer activity in vitro. $\mathrm{The}^{\mathrm{IC}_{50}}$ values of A549 cells and LLC cells treated with DTX and DTX-DHA were calculated and are presented in Table I (OD data not shown). The $\mathrm{IC}_{50}$ values of DTX-DHA were similar to those of DTX for A549 and LLC cells, indicating that the in vitro anti-cancer activities of DTX-DHA were similar to those of DTX (24).

Cell migration assay. Migration ability was measured in LLC murine Lewis lung carcinoma cells and compared with tumor cells administered with $50 \mathrm{nM}$ DTX or DTX-DHA using a Transwell migration assay (Fig. 2A-C). Treatment with DTX-DHA significantly inhibited tumor cell migration 
Table II. Determination of MTD following intravenous injection of DTX or DTX-DHA.

\begin{tabular}{|c|c|c|c|c|c|}
\hline Compound & Dosage, $\mu \mathrm{mol} / \mathrm{kg}$ & Observation post injection & Lethality & Weight change, $\%$ & $\mathrm{MTD}, \mu \mathrm{mol} / \mathrm{kg}$ \\
\hline \multirow[t]{7}{*}{ DTX } & 5 & Well tolerated & $0 / 3$ & +1.1 & 15 \\
\hline & 10 & Loss of appetite & $0 / 3$ & -3.2 & \\
\hline & 15 & Apathy, Catatonia & $0 / 3$ & -5.8 & \\
\hline & 20 & Apathy, Catatonia & $0 / 3$ & -10.5 & \\
\hline & 25 & Prostration & $1 / 3$ & -14.5 & \\
\hline & 30 & Apathy, prostration & $3 / 3$ & $>-20$ & \\
\hline & 35 & Apathy, Catatonia, prostration & $3 / 3$ & $>-20$ & \\
\hline \multirow[t]{7}{*}{ DTX-DHA } & 5 & Well-tolerated & $0 / 3$ & +30.9 & 25 \\
\hline & 10 & Well-tolerated & $0 / 3$ & +28.4 & \\
\hline & 15 & Well-tolerated & $0 / 3$ & +25.6 & \\
\hline & 20 & Well-tolerated & $0 / 3$ & +11.6 & \\
\hline & 25 & Well-tolerated & $0 / 3$ & +2.6 & \\
\hline & 30 & Loss of appetite & $0 / 3$ & -10.8 & \\
\hline & 35 & Apathy, Catatonia & $1 / 3$ & $>-20$ & \\
\hline
\end{tabular}

DTX, docetaxel; DTX-DHA, docosahexaenoic acid-conjugated docetaxel; MTD, maximum tolerated dose.

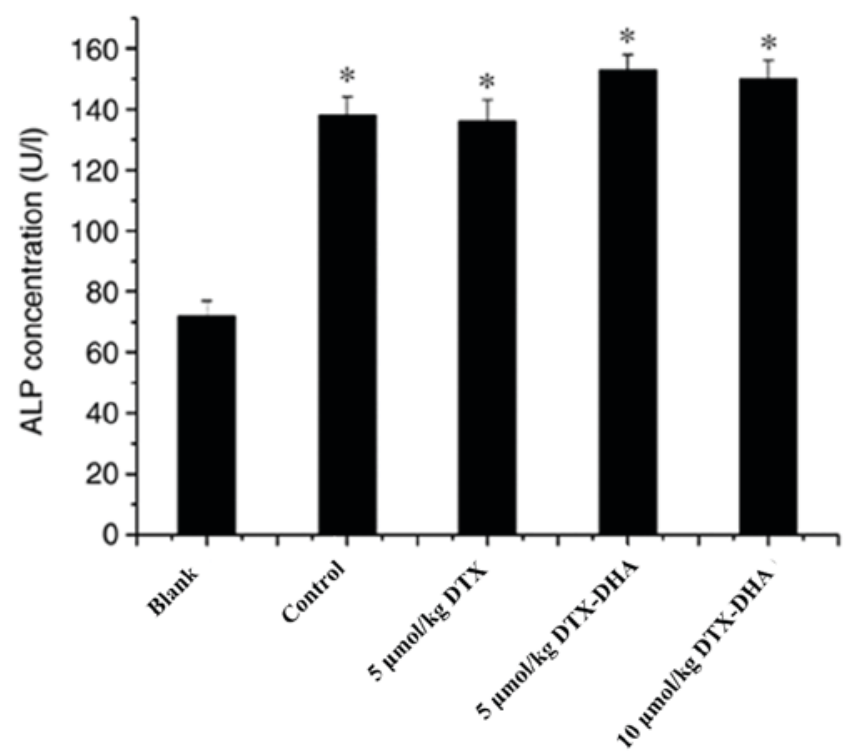

Figure 4. Two weeks after the initial dose, the serum ALP concentrations of the mice were determined prior to sacrifice. The mice from blank group were not implanted with murine Lewis lung carcinoma cells, and the mice from other groups were implanted with murine Lewis lung carcinoma cells subsequent to being injected with normal saline, $5 \mu \mathrm{mol} / \mathrm{kg}$ DTX, $5 \mu \mathrm{mol} / \mathrm{kg}$ DTX-DHA, $10 \mu \mathrm{mol} / \mathrm{kg}$ DTX-DHA. n=3/group. Each value represents the mean \pm standard deviation. Data were analyzed using one-way analysis of variance with Newman-Keuls post-hoc test. "P<0.01 vs. blank group. ALP, alkaline phosphatase; DTX, docetaxel; DTX-DHA, docosahexaenoic acid-conjugated docetaxel.

$\left({ }^{*} \mathrm{P}<0.01\right.$ vs. control). The cell transmittance of the $50 \mathrm{nM}$ DTX-DHA group was $36.46 \pm 3.56 \%$, and that of the $50 \mathrm{nM}$ DTX group was $81.62 \pm 3.52 \%$ (Fig. 2D).

Osteoclast-induced formation assay. The osteoclast-induced formation assay was performed with TRAP staining. The majority of cells in the negative control group were stained

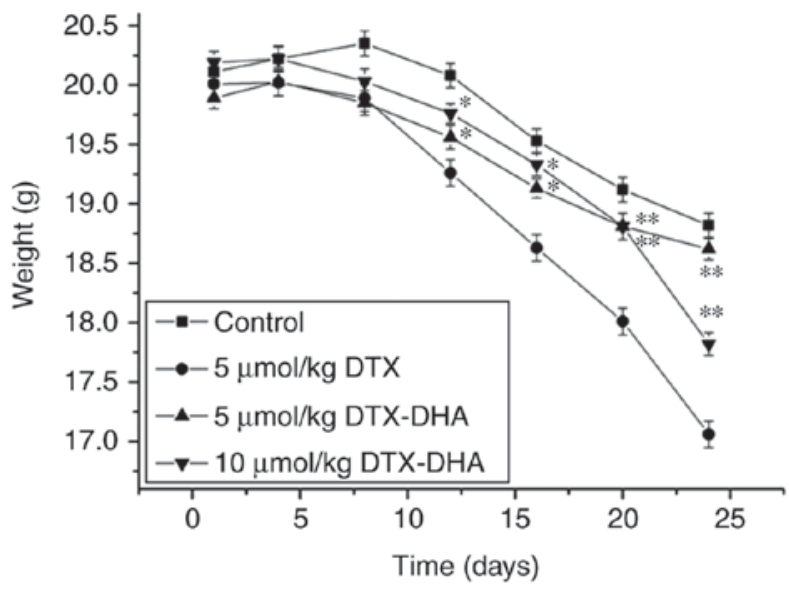

Figure 5. The body weight of C57BL/6 mice implanted with murine Lewis lung carcinoma cells subsequent to being injected with normal saline, $5 \mu \mathrm{mol} / \mathrm{kg}$ DTX, $5 \mu \mathrm{mol} / \mathrm{kg}$ DTX-DHA and $10 \mu \mathrm{mol} / \mathrm{kg}$ DTX-DHA. The body weight of the mice was measured once daily until the mice succumbed. $n=20 /$ group. Each value represents the mean \pm standard deviation. Data were analyzed using one-way analysis of variance with Newman-Keuls post-hoc test. ${ }^{* *} \mathrm{P}<0.01,{ }^{*} \mathrm{P}<0.05$, vs. $5 \mu \mathrm{mol} / \mathrm{kg}$ DTX group. DTX, docetaxel; DTX-DHA, docosahexaenoic acid-conjugated docetaxel.

light red, and the majority of cells in the $50 \mathrm{nM}$ DTX group, $50 \mathrm{nM}$ DTX-DHA group and $250 \mathrm{nM}$ DTX-DHA group were stained purple. In total, $246 \pm 5,151 \pm 6,154 \pm 7$ and $149 \pm 5$ osteoclast cells $/ \mathrm{cm}^{2}$ were generated in the negative control group, $50 \mathrm{nM}$ DTX group, $50 \mathrm{nM}$ DTX-DHA group and $250 \mathrm{nM}$ DTX-DHA group respectively. This indicated that DTX and DTX-DHA exerted similar inhibiting effects on RAW 264.7 murine macrophage cells forming osteoclasts (Fig. 3).

Evaluation of MTD. In order to further develop the targeted drug into a clinically applicable form, a series of preclinical animal studies were performed. The MTD of DTX-DHA and DTX administered intravenously was determined in 


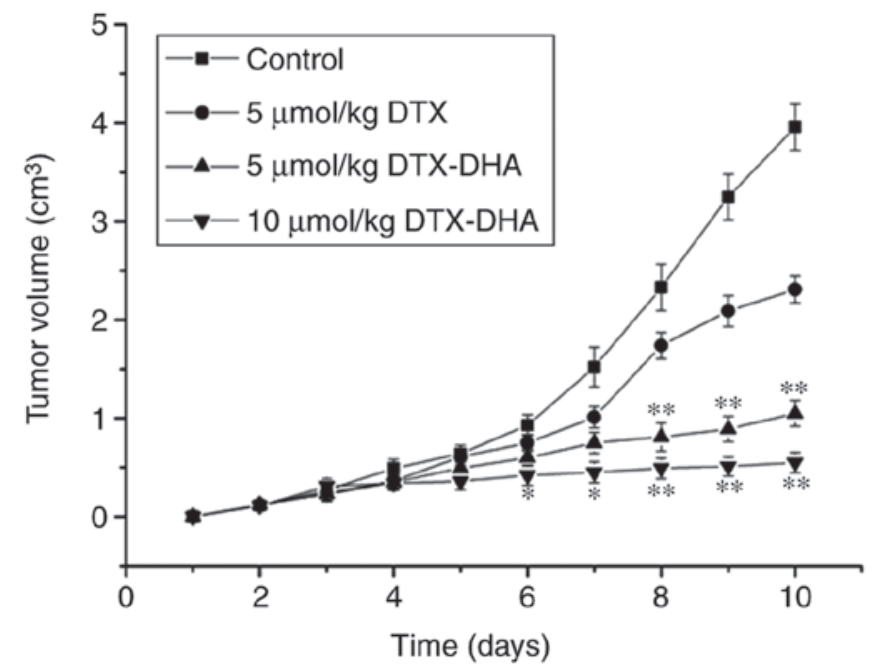

Figure 6. The tumor volume of the C57BL/6 mice implanted with LLC murine Lewis lung carcinoma cells subsequent to being injected with normal saline, $5 \mu \mathrm{mol} / \mathrm{kg}$ DTX, $5 \mu \mathrm{mol} / \mathrm{kg}$ DTX-DHA and $10 \mu \mathrm{mol} / \mathrm{kg}$ DTX-DHA. $n=20 /$ group. Each value represents the mean \pm standard deviation, data were analyzed using a one-way analysis of variance with Newman-Keuls post-hoc test. ${ }^{*} \mathrm{P}<0.05,{ }^{* *} \mathrm{P}<0.01$ vs. $5 \mu \mathrm{mol} / \mathrm{kg}$ DTX group. DTX, docetaxel; DTX-DHA, docosahexaenoic acid-conjugated docetaxel.

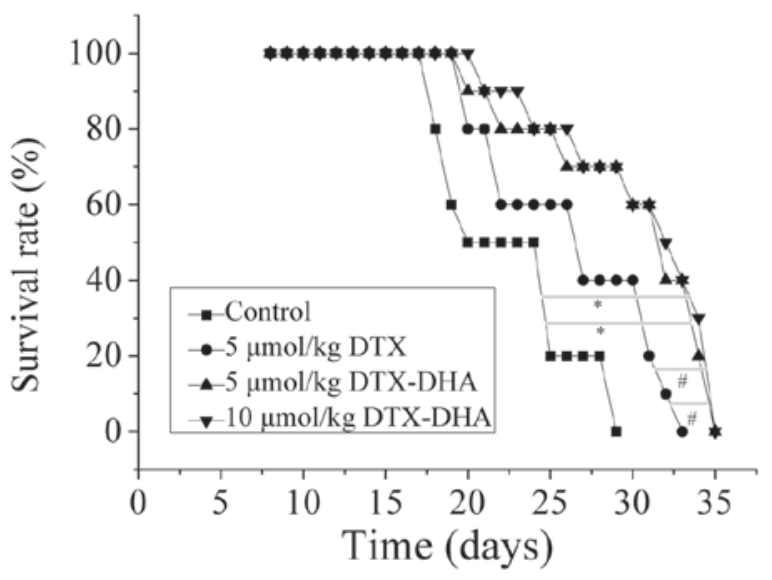

Figure 7. Kaplan-Meier survival curves of the C57BL/6 mice implanted with LLC murine Lewis lung carcinoma cells following treatment with saline, $5 \mu \mathrm{mol} / \mathrm{kg}$ DTX, $5 \mu \mathrm{mol} / \mathrm{kg}$ DTX-DHA and $10 \mu \mathrm{mol} / \mathrm{kg}$ DTX-DHA. $\mathrm{n}=20 /$ group. Each value represents the mean \pm SD. Data were analyzed using a one-way analysis of variance with Newman-Keuls post-hoc test. ${ }^{*} \mathrm{P}<0.01$ vs. control group, ${ }^{\#} \mathrm{P}<0.01$ vs. $5 \mu \mathrm{mol} / \mathrm{kg}$ DTX group. DTX, docetaxel; DTX-DHA, docosahexaenoic acid-conjugated docetaxel.

C57BL/6 mice. The MTD of DTX-DHA was determined by a dose escalation study followed by daily body weight measurement and observation of general signs of toxicity. The results indicated that the MTD of DTX was $15 \mu \mathrm{mol} / \mathrm{kg}$ and the MTD of DTX-DHA was $25 \mu \mathrm{mol} / \mathrm{kg}$ (Table II). The MTD of DTX-DHA was increased by 1.5 -fold compared with DTX.

In vivo assay of anti-cancer efficacy on lung cancer metastasis to bone. Serum ALP functions as a sensitive index for evaluating whether a bone metastasis model has been successfully established. The ALP concentration in each group is presented in Fig. 4. The results indicated that the serum ALP concentration of the four model groups (negative control group, DTX group, $5 \mu \mathrm{mol} / \mathrm{kg}$ DTX-DHA group and $10 \mu \mathrm{mol} / \mathrm{kg}$ DTX-DHA group) was increased compared with the blank group (not implanted with LLC cells). Mice implanted with LLC cells exhibited an increased ALP concentration, which suggested that the model of bone metastasis of lung cancer in the C57BL/6 mice had been successfully established.

To investigate the activity of the targeted drug on lung tumor growth and metastasis, the aforementioned bone metastasis of lung tumor model was employed. The observations of mice indicated that they started losing hair at day 7 , beginning with the right hind limb. The mice moved less with swollen right hind limbs. There was no obvious weight loss in the mice in the DTX-DHA-treated group during the administration period. However, DTX significantly decreased the body weight of animals on day 12 , indicating that DTX was toxic to the animals (Fig. 5) ( $\mathrm{P}<0.01$ vs. control). The tumor volumes in the untreated control group were increased compared with the drug-treated control group and the DTX group (Fig. 6). Once the mice had been intraperitoneally administered for 10 days, the mean tumor weight of the control group $\left(3.96 \pm 0.24 \mathrm{~cm}^{3}\right)$ was greatest, followed by the $5 \mu \mathrm{mol} / \mathrm{kg}$ DTX group $\left(2.31 \pm 0.14 \mathrm{~cm}^{3}\right)$, then the $5 \mu \mathrm{mol} / \mathrm{kg}$ DTX-DHA group $\left(1.05 \pm 0.13 \mathrm{~cm}^{3}\right)$. The lowest tumor weight was in the $10 \mu \mathrm{mol} / \mathrm{kg}$ DTX-DHA group $\left(0.55 \pm 0.10 \mathrm{~cm}^{3}\right)$. The mean survival of the mice in the negative control group, $5 \mu \mathrm{mol} / \mathrm{kg}$ DTX group, $5 \mu \mathrm{mol} / \mathrm{kg}$ DTX-DHA group and $10 \mu \mathrm{mol} / \mathrm{kg}$ DTX-DHA group was $20.7 \pm 4.17,26.1 \pm 5.68,29.6 \pm 5.28$ and $30.6 \pm 4.76$ days, respectively (Fig. 7). The overall survival of the DTX-DHA group was increased compared with that of the positive control (DTX) group. The results demonstrated that the mice with bone metastasis of lung cancer treated with DTX-DHA survived significantly longer compared with those treated with DTX (*P<0.01 vs. DTX group).

$X$-ray radiography. Four weeks after the initial dose, the $\mathrm{X}$-ray radiography images of the four model groups were captured (Fig. 8A-D). A total of 20,12, 8 and 7 mice had severe tissue injury in the negative control group, positive control group (5 $\mu \mathrm{mol} / \mathrm{kg}$ DTX group), $5 \mu \mathrm{mol} / \mathrm{kg}$ DTX-DHA group and $10 \mu \mathrm{mol} / \mathrm{kg}$ DTX-DHA group, respectively (Fig. 8; white arrow). The radiolucent osteolytic areas of bone metastasis were quantified for murine Lewis lung carcinoma cells using a computer-assisted Quantity One analysis program (Fig. 8E). The results demonstrated that DTX-DHA exerts a greater anti-cancer efficiency on bone metastasis compared with DTX.

Histopathological identification. Four weeks after the initial dose, mice were sacrificed and bones were collected and fixed in formalin. Following decalcification, paraffin-embedded bone sections were prepared and stained with H\&E to determine the lung tumor burden in bones. The images obtained from H\&E staining are presented in Fig. 9A-D. Tumor areas were quantified using Image-Pro Plus software. There were fewer healthy cells in the negative control group and positive control group ( $5 \mu \mathrm{mol} / \mathrm{kg}$ DTX group) compared with the two DTX-DHA groups (Fig. 9E), which further suggested that the mice with bone metastasis of lung cancer treated with DTX-DHA had less bone tissue damage. 
A

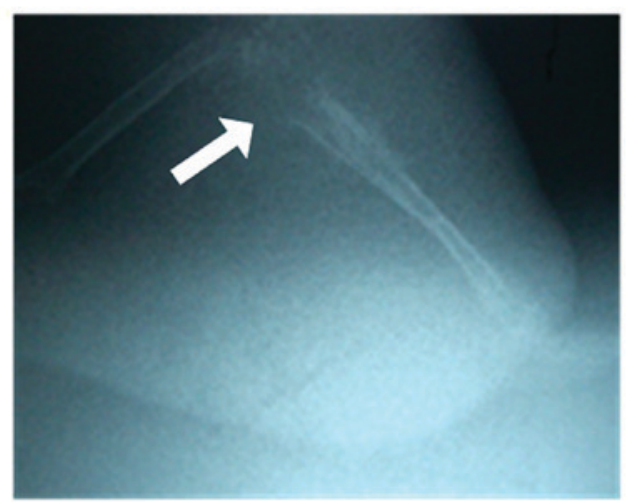

C $\quad 5 \mu \mathrm{mol} / \mathrm{kg}$ DTX-DHA
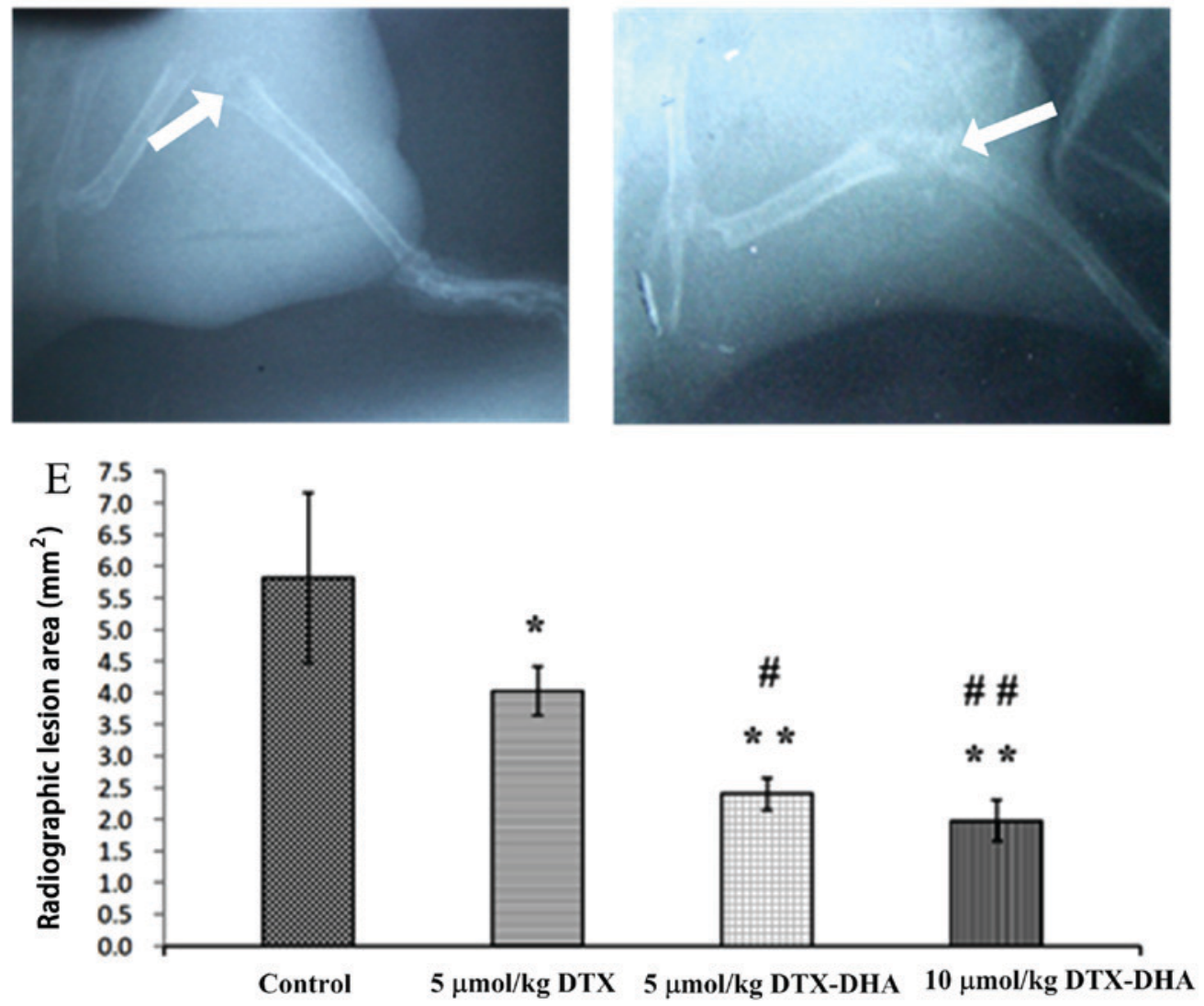

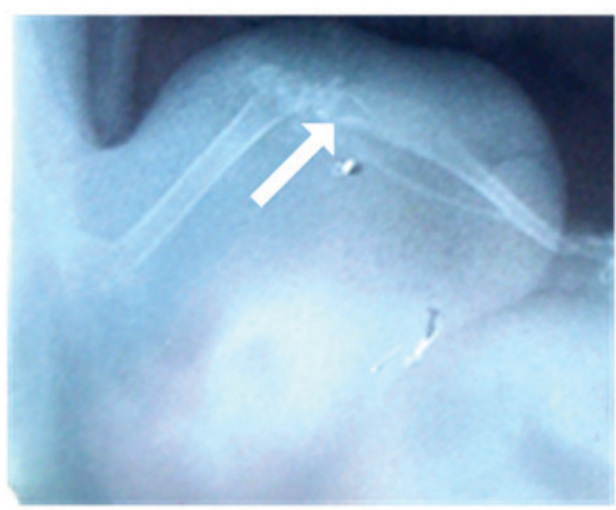

D $\quad 10 \mu \mathrm{mol} / \mathrm{kg}$ DTX-DHA

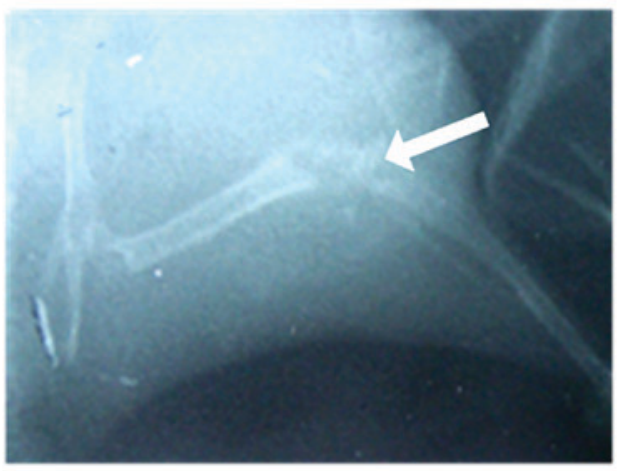

\section{B $\quad 5 \mu \mathrm{mol} / \mathrm{kg}$ DTX}

Figure 8. X-ray radiography images of the four model groups, indicating osteolytic lesions. Four weeks after the initial injection, mice were imaged using X-ray machines and representative images from the (A) control, (B) $5 \mu \mathrm{mol} / \mathrm{kg}$ DTX, (C) $5 \mu \mathrm{mol} / \mathrm{kg}$ DTX-DHA and (D) $10 \mu \mathrm{mol} / \mathrm{kg}$ DTX-DHA groups are presented. Magnification, x1. (E) The radiolucent osteolytic areas of bone metastasis were quantified for LLC murine Lewis lung carcinoma cells using a computer-assisted Quantity One analysis program. $n=4$ group. Each value represents the mean \pm standard deviation. Data were analyzed using a one-way analysis of variance with Newman-Keuls post-hoc test. ${ }^{*} \mathrm{P}<0.05$ vs. control group, ${ }^{* *} \mathrm{P}<0.01$ vs. control group, ${ }^{*} \mathrm{P}<0.05$ vs. $5 \mu$ mol $/ \mathrm{kg}$ DTX group, ${ }^{\# \#} \mathrm{P}<0.01$ vs. $5 \mu \mathrm{mol} / \mathrm{kg}$ DTX group. DTX, docetaxel; DTX-DHA, docosahexaenoic acid-conjugated docetaxel.

\section{Discussion}

DTX exhibits a broad spectrum of activity against a variety of tumor types, particularly non-small cell lung cancer, breast cancer and esophago-gastric cancer (29). However, DTX is nonspecific and toxic; and its efficacy is dose-dependent and is primarily limited by hematological and cardiac toxicities. A tumor-targeted drug delivery system that enhances cytotoxicity of DTX to tumor tissue while sparing normal tissues has the potential to increase survival (29). 


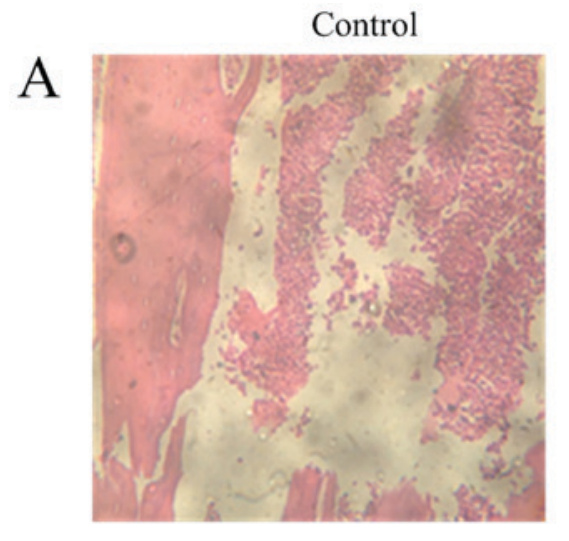

$5 \mu \mathrm{mol} / \mathrm{kg}$ DTX-DHA

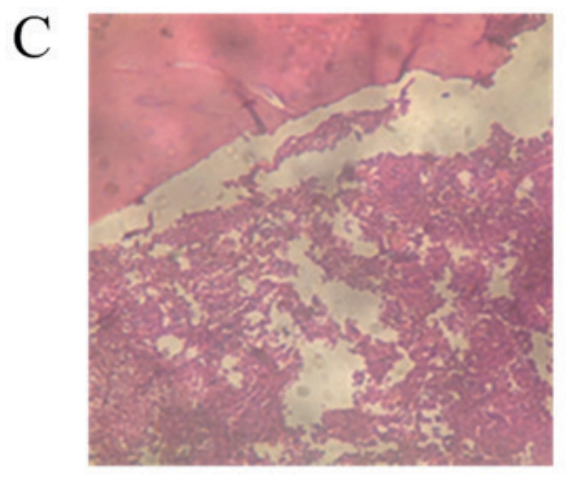

$\mathrm{B}$

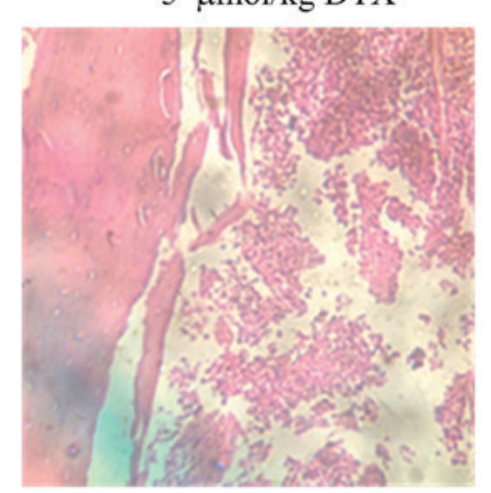

$10 \mu \mathrm{mol} / \mathrm{kg}$ DTX-DHA

$\mathrm{D}$

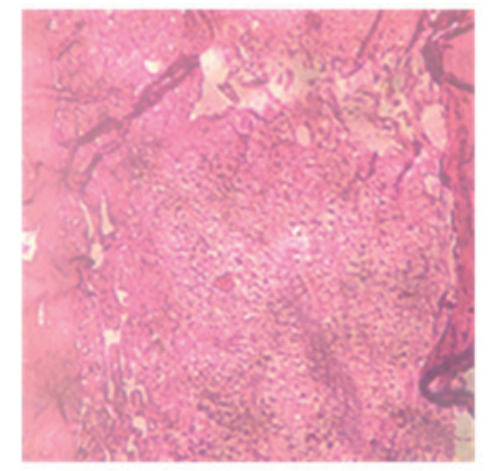

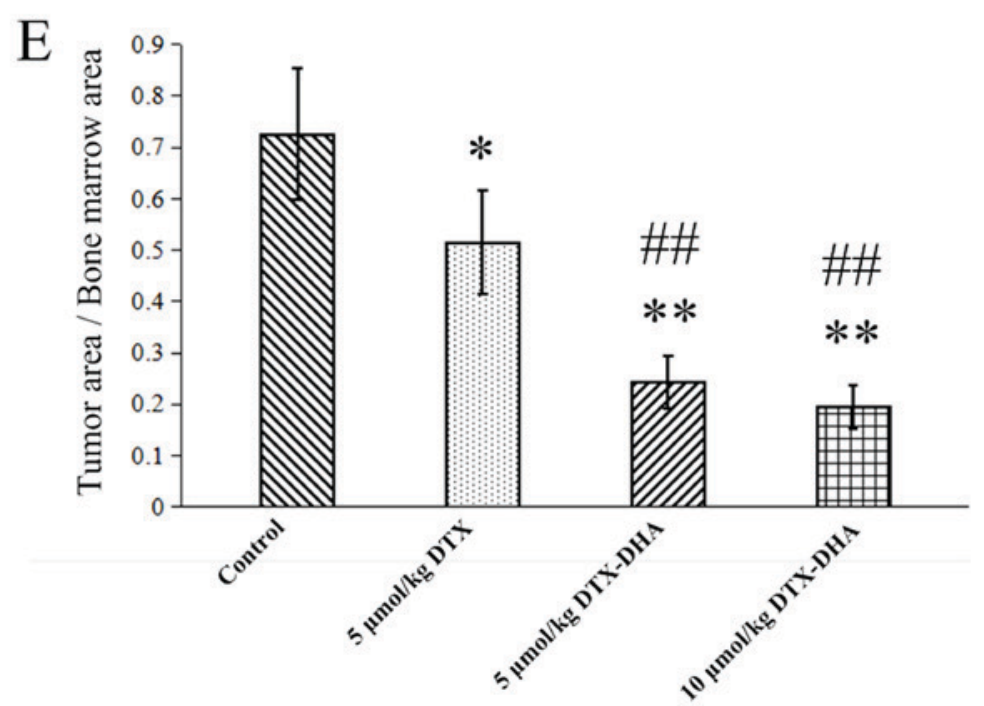

Figure 9. Four weeks after the initial injection, light microscopy images were obtained indicating the HE-stained bones of mice implanted with murine Lewis lung carcinoma cells. (A) Normal saline, (B) $5 \mu \mathrm{mol} / \mathrm{kg}$ DTX, (C) $5 \mu \mathrm{mol} / \mathrm{kg}$ DTX-DHA and (D) $10 \mu \mathrm{mol} / \mathrm{kg}$ DTX-DHA. Magnification, x200. (E) Tumor areas were quantified using Image-Pro Plus software. $n=4 /$ group. Each value represents the mean \pm standard deviation. Data were analyzed using a one-way analysis of variance with Newman-Keuls post-hoc test. ${ }^{*} \mathrm{P}<0.05$ vs. control group, ${ }^{* *} \mathrm{P}<0.01 \mathrm{vs}$. control group, ${ }^{\# \prime} \mathrm{P}<0.01$ vs. $5 \mu$ mol $/ \mathrm{kg}$ DTX group. DTX, docetaxel; DTX-DHA, docosahexaenoic acid-conjugated docetaxel.

active at the $\mu \mathrm{M}$ range $(24,25)$. By contrast, the $\mathrm{IC}_{50}$ values of DTX-DHA were similar to those of DTX for A549 and LLC cells (Table I). A possible reason for this is that a longer retention time of DTX-DHA in tumor cells is beneficial to hydrolyze DTX-DHA back to DTX $(24,31)$. The MTD of DTX-DHA in vivo was increased compared with DTX, thus it is speculated that DTX-DHA is primarily confined to the plasma compartment of mice and DTX is released slowly (3).
The mice with bone metastasis from lung cancer that were treated with DTX-DHA lived significantly longer compared with those treated with DTX. It is possible that DTX-DHA exerts its effects not only by targeting tumor tissues, but also via its hydrolysis products (DHA and DTX), which may exhibit a synergistic antitumor effect $(12,13)$.

Lung cancer cells growing in bone cannot directly destroy the bone tissue, but they may induce osteoclasts to participate in bone resorption by releasing specific cell stimulating 
factors $(32,33)$. In order to further identify the targeting cells of DTX-DHA, osteoclast-induced formation and tumor cell migration assays were performed (33). LLC cell migration was inhibited to a greater extent in the DTX-DHA group compared with the positive control group (DTX group), but DTX and DTX-DHA possessed a similar inhibitory effect induction of RAW 264.7 cells to osteoclasts. DTX-DHA inhibited bone metastasis of lung cancer primarily through affecting lung cancer cell migration, which indicated that DTX-DHA could target the tumor cells $(34,35)$. Therefore, it is not surprising that DTX-DHA significantly improved overall survival and exhibited decreased bone tissue damage ( $\mathrm{P}<0.01$ vs. DTX group). For a bone-modifying agent targeting osteoclast cells instead of tumor cells, the bone-modifying agent can reduce skeletal-associated events but not improve overall survival significantly (36).

In the present study, DTX-conjugated DHA was successfully prepared using a chemosynthesis technique. The toxicity studies performed in mice indicated that DTX-DHA is less toxic than DTX. DTX-DHA had an increased tumor-targeting capacity, stronger anti-cancer activity in vivo and superior efficiency for inhibiting lung cancer metastasis to bone compared with DTX. Furthermore, the overall survival of the DTX-DHA group was significantly increased compared with the DTX group. These results suggest that DTX-DHA may provide a promising therapeutic approach for treating lung cancer metastasis to bone.

\section{Acknowledgements}

Not applicable.

\section{Funding}

The present study was funded by the Fundamental Research Funds for the Central Universities (grant no. 2572018BU03), the Science Foundation of Heilongjiang Province,China (grant no. H2018001) and the Heilongjiang Postdoctoral (grant no. LBH-Z10282).

\section{Availability of data and materials}

All data generated or analyzed during this study are included in this published article.

\section{Authors' contributions}

SJ, ZL and YZ were the principal investigators, and were responsible for the conception and design of the study. SJ was a major contributor in writing the manuscript. $\mathrm{LWu}$ performed the synthesis, cell migration assay and osteoclast-induced formation assay. YY performed the determination of anti-cancer activity in vitro. $\mathrm{LWu}$ and $\mathrm{YH}$ performed the assay of anti-cancer efficacy in vivo. $\mathrm{XZ}$ performed the histological examination of the bone. LWe performed the statistical analysis. All authors read and approved the final manuscript.

\section{Ethics approval and consent to participate}

All animal procedures complied with the revised Animals (Scientific Procedures) Act 1986 in the UK and Directive 2010/63/EU in Europe and were performed following a protocol approved by the Institutional Animal Care and Use Committee at The State Engineering Laboratory of Bio-Resources Eco-Utilization, Northeast Forestry University (Harbin, China).

\section{Patient consent for publication}

Not applicable.

\section{Competing interests}

The authors declare that they have no competing interests.

\section{References}

1. LeVasseur N, Clemons M, Hutton B, Shorr R and Jacobs C: Bone-targeted therapy use in patients with bone metastases from lung cancer: A systematic review of randomized controlled trials. Cancer Treat Rev 50: 183-193, 2016.

2. Lazzari C, Bulotta A, Ducceschi M, Viganò MG, Brioschi E, Corti F, Gianni L and Gregore V: Historical evolution of second-line therapy in non-small cell lung cancer. Front Med (Lausanne) 4: 4, 2017.

3. Socinski MA: Update on taxanes in the first-line treatment of advanced non-small-cell lung cancer. Curr Oncol 21: e691-e703, 2014.

4. Kenmotsu H and Tanigawara Y: Pharmacokinetics, dynamics and toxicity of docetaxel: Why the japanese dose differs from the western dose. Cancer Sci 106: 497-504, 2015.

5. Kan C, Vargas G, Pape FL and Clézardin P: Cancer cell colonisation in the bone microenvironment. Int J Mol Sci 17: E1674, 2016.

6. Popper HH: Progression and metastasis of lung cancer. Cancer Metastasis Rev 35: 75-91, 2016.

7. Stafford JH and Thorpe PE: Increased exposure of phosphatidylethanolamine on the surface of tumor vascular endothelium. Neoplasia 13: 299-308, 2011.

8. Fahrmann JF, Grapov D, Defelice BC, Taylor S, Kim K, Kelly K, Wikoff WR, Pass H, Rom WN, Fiehn O and Miyamoto S: Serum phosphatidylethanolamine levels distinguish benign from malignant solitary pulmonary nodules and represent a potential diagnostic biomarker for lung cancer. Cancer Biomark 16: 609-617, 2016.

9. Li S, Qin J, Tian C, Cao J, Fida G, Wang Z, Chen H, Qian Z, Chen WR and $\mathrm{Gu}$ Y: The targeting mechanism of DHA ligand and its conjugate with gemcitabine for the enhanced tumor therapy. Oncotarget 5: 3622-3635, 2014.

10. Riediger ND, Othman RA, Suh M and Moghadasian MH: A systemic review of the roles of n-3 fatty acids in health and disease. J Am Diet Assoc 109: 668-679, 2009.

11. Rahman MM, Veigas JM, Williams PJ and Fernands G: DHA is a more potent inhibitor of breast cancer metastasis to bone and related osteolysis than EPA. Breast Cancer Res Treat 141: 341-352, 2013.

12. Murphy RA, Mourtzakis M, Chu QS, Baracos VE, Reiman T and Mazurak VC: Supplementation with fish oil increases first-line chemotherapy efficacy in patients with advanced nonsmall cell lung cancer. Cancer 117: 3774-3780, 2011.

13. Sánchez-Lara K, Turcott JG, Juárez-Hernández E, Nuñez-Valencia C, Villanueva G, Guevara $P$, De la Torre-Vallejo M, Mohar A and Arrieta O: Effects of an oral nutritional supplement containing eicosapentaenoic acid on nutritional and clinical outcomes in patients with advanced non-small cell lung cancer: Randomised trial. Clin Nutr 33: 1017-1023, 2014.

14. Mai J, Huang Y, Mu C, Zhang G, Xu R, Guo X, Xia X, Volk DE, Lokesh GL, Thiviyanathan V, et al: Bone marrow endothelium-targeted therapeutics for metastatic breast cancer. J Control Release 187: 22-29, 2014.

15. Yates CM, Tull SP, Madden J, Calder PC, Grimble RF, Nash GB and Rainger GE: Docosahexaenoic acid inhibits the adhesion of flowing neutrophils to cytokine stimulated human umbilical vein endothelial cells. J Nutr 141: 1331-1334, 2011.

16. Chauvin L, Goupille C, Blanc C, Pinault M, Domingo I, Guimaraes C, Bougnoux P, Chevalier S and Mahéo K: Long chain $n-3$ polyunsaturated fatty acids increase the efficacy of docetaxel in mammary cancer cells by downregulating Akt and PKC $\varepsilon / \delta$-induced ERK pathways. Biochim Biophys Acta 1861: 380-390, 2016. 
17. Zu Y, Hu Y, Yu X and Jiang S: Docetaxel-loaded bovine serum albumin nanoparticles conjugated docosahexaenoic acid for inhibiting lung cancer metastasis to bone. Anticancer Agents Med Chem 17: 542-551, 2017.

18. Jiang S, Gong X, Zhao X and Zu Y: Preparation, characterization, and antitumor activities of folate-decorated docetaxel-loaded human serum albumin nanoparticles. Drug Deliv 22: 206-213, 2015.

19. Bölükbas DA and Meiners S: Lung cancer nanomedicine: Potentials and pitfalls. Nanomedicine (Lond) 10: 3203-3212, 2015.

20. Bedikian AY, DeConti RC, Conry R, Aqarwata S, Papadopoulos N, Kim KB and Ernstoff M: Phase 3 study of docosahexaenoic acid-paclitaxel versus dacarbazine in patients with metastatic malignant melanoma. Ann Oncol 22: 787-793, 2011.

21. Payne M, Ellis P, Dunlop D, Ranson M, Danson S, Schacter L and Talbot D: DHA-paclitaxel (Taxoprexin) as first-line treatment in patients with stage IIIB or IV non-small cell lung cancer: Report of a phase ii open-label multicenter trial. J Thorac Oncol 1: 984-990, 2006.

22. Jones RJ, Hawkins RE, Eatock MM, Ferry DR, Eskens FA, Wilke $\mathrm{H}$ and Evans TR: A phase II open-label study of DHA-paclitaxel (Taxoprexin) by 2-h intravenous infusion in previously untreated patients with locally advanced or metastatic gastric or oesophageal adenocarcinoma. Cancer Chemother Pharmacol 61: 435-441, 2008.

23. Harries M, O'Donnell A, Scurr M, Reade S, Cole C, Judson I, Greystoke A, Twelves C and Kaye S: Phase I/II study of DHA-paclitaxel in combination with carboplatin in patients with advanced malignant solid tumours. Br J Cancer 91: 1651-1655, 2004.

24. Bradley MO, Webb NL, Anthony FH, Devanesan P, Witman PA, Hemamalini S, Chander MC, Baker SD, He L, Horwitz SB and Swindell CS: Tumor targeting by covalent conjugation of a natural fatty acid to paclitaxel. Clin Cancer Res 7: 3229-3238, 2001.

25. Sparreboom A, Wolff AC, Verweij J, Zabelina Y, van Zomeren DM, McIntire GL, Swindell CS, Donehower RC and Baker SD: Disposition of docosahexaenoic acid-paclitaxel, a novel taxane, in blood: In vitro and clinical pharmacokinetic studies. Clin Cancer Res 9: 151-159, 2003.
26. Chu J and Ding J: Plumbagin prevents bone metastasis of lung adenocarcinoma cell line PC9 by inhibiting migration and osteolysis. Med Innovation China 11: 11-13, 2014 (In Chinese).

27. Liu F, Feng L, Zhang L, Zhang X and Zhang N: Synthesis, characterization and antitumor evaluation of CMCS-DTX conjugates as novel delivery platform for docetaxel. Int J Pharm 451: 41-49, 2013.

28. Hoang B, Ernsting MJ, Tang WS, Bteich J, Undzys E, Kiyota T and Li SD: Cabazitaxel-conjugated nanoparticles for docetaxel-resistant and bone metastatic prostate cancer. Cancer Lett 410: 169-179, 2017.

29. Yared JA and Tkaczuk KH: Update on taxane development: New analogs and new formulations. Drug Des Devel Ther 6: 371-384, 2012.

30. Ray A, Larson N, Pike DB, Grüner M, Naik S, Bauer H, Malugin A, Greish K and Ghandehari H: Comparison of active and passive targeting of docetaxel for prostate cancer therapy by HPMA copolymer-RGDfK conjugates. Mol Pharm 8: 1090-1099, 2011.

31. Gligorov J and Lotz JP: Preclinical pharmacology of the taxanes: Implications of the differences. Oncologist 9 (Suppl 2): S3-S8, 2004.

32. Roato I: Bone metastases: When and how lung cancer interacts with bone. World J Clin Oncol 5: 149-155, 2014.

33. Luo Q, Xu Z, Wang L, Ruan M and Jin G: Progress in the research on the mechanism of bone metastasis in lung cancer. Mol Clin Oncol 5: 227-235, 2016.

34. Siddiqui RA, Harvey KA, Xu Z, Bammerlin EM, Walker C and Altenburg JD: Docosahexaenoic acid: A natural powerful adjuvant that improves efficacy for anticancer treatment with no adverse effects. Biofactors 37: 399-412, 2011.

35. Merendino N, Costantini L, Manzi L, Molinari R, D'Eliseo D and Velotti F: Dietary $\omega-3$ polyunsaturated fatty acid DHA: A potential adjuvant in the treatment of cancer. Biomed Res Int 2013: 310186, 2013.

36. Vicent S, Perurena N, Govindan R and Lecanda F: Bone metastases in lung cancer. Potential novel approaches to therapy. Am J Respir Crit Care Med 192: 799-809, 2015.

(i) $($ This work is licensed under a Creative Commons cc ${ }_{\text {BY NO ND }}$ Attribution-NonCommercial-NoDerivatives 4.0 International (CC BY-NC-ND 4.0) License. 